\title{
Regulations Availability in the Management of Community Based Tourism (CBT) Villages in the Village of Jatiluwih
}

\author{
Ratna Artha Windari, I Gusti Ayu Apsari Hadi
}

\begin{abstract}
The tourism sector that is generally developed in Bali came by promoting cultural tourism. This is in accordance with the policy of Baly Provincial Regulation No. 2 Year 2012 on Balinese Culture Tourism. One of the manisfestations of cultural tourism is in the form of a tourist village. The tourist village is one of tourism activities aimed at tourists who want to enjoy the rural atmosphere as a place to rest, learn the uniqueness of a region (dancing, panting,sculpting) and a place to get different life experience from the area of origin. However in the empirical realm of tourism management, especially the tourist village is still done with economic approaches that only emphasizes the investors interest and sometimes ignore the sustainability of the environment and local communities. An appropriate policy is needed in order to involve the role of the community in the management of a tourist village. This study was conducted to assess the availability of regulations in Jatiluwih village both in the form of rules and related decisions in the management of tourist village and also to actualization of CBT system in Jatiluwih. This paper shows participation of the community in the management of Jatiluwih tourism village is still very minimal. The fact is, the radip investment in jatiluwih village shows the increasingly marginal opportunity of local people to develoing their business. So do the policy of local government related tourism villages in Jatiluwih is still very minimal. The Mutual Agreement between Local Government of Tabanan District with Jatiluwih village is only about revenue sharing of visitor every year. However with the distribution income based on Mutual Agreement at least the local community is no longer needs to pay obligatory dues at the time of religious ceremony so it can be relieve the cost for religious ceremonies.
\end{abstract}

Keywords - Regulations, Availability, Management, CBT, Village Jatiluwih.

\section{INTRODUCTION}

Tourism is one of the leading sectors in Bali besides agriculture, small industries and medium industries. Development of this sector is considered to be one of the steps to create community welfare. There are various efforts made by the Government both at the district / city level in Bali in order to develop local potentials so as to attract tourists continue to visit the Island of the Gods.

Tourism that is generally developed in Bali is cultural tourism. This is in accordance with the Provincial Regulation Number 2 year 2012 on Balinese Culture Tourism. According to
Article 1 Number 14/2012 on Bali Culture Tourism; Bali tourism based on Balinese culture inspired by the teachings of Hindus Religion and the Tri Hita Karana philosophy as the main potential by using tourism as the mode of its actualization, resulting in a Dynamic reciprocal relationship between the tourism and culture that makes them grow synergistically, harmoniously and sustainably to be able to provide prosperity to society, cultural and environmental sustainability.

However in the empirical realm of tourism development policy, is solely done with an economic approach and ignores the environmental sustainability and interests of local communities. The entrance of the capitalists in the development of tourism in Bali indirectly build an area of economic competition. This competition is not only in the struggle for employment but also in terms of fund. One example in the field is the development of Tourism Village in Jatiluwih that has not taken sides to the community. Rice fields and farmers are a tourism asset that is sold to the satisfaction of tourists but the development of tourist villages does not side with the life of farmers.

The existence of Jatiluwih village with the typical charm of rice terraces has been recognized as one of the main strengths of tourism in Bali and in the eyes of the world. A stretch of nearly 303 hectares ${ }^{1}$ of paddy fields inaugurated as a world cultural heritage in 2012 by UNESCO with architecture as Cultural Landscape of Bali Province : Subak System as Manifestation of Tri Hita Karana Philosophy. Along that with the recognition of the government of Tabanan District confirmed with the Decree of the Regent of Tabanan 180/337/03 / HK \& HAM / 2016 on Stipulation of Jatiluwih Village as Tourism Village in Tabanan Regency.

After the issuance of the Decree of the Regent of Tabanan Year 2016, there has not been any significant changes, especially for the improvement of the people's economy. This is proven by the development of villas and restaurants that in fact is owned by investors. Although indeed with the growing development of villas and restaurants will the field of employment and business opportunities will increase as well. However, these improvements have not provided optimal economic benefits for local communities.

When looking at the existing regulations; the management of tourist villages, especially in Jatiluwih not only contained in the Decree of the Regent of Tabanan Year 2016 on the Determination of Jatiluwih Village as a Tourism Village, but

\footnotetext{
${ }^{1}$ The results of interview with Village Secretary of Jatiluwih.
} 
also in Tabanan District Regulation number 11 of 2012 on Spatial Planning of Tabanan Regency Year 2012 - 2032 which in Article 51 Paragraph (4) states that Jatiluwih Tourism Village becomes Tourism Attraction (DTW) which is intended as a nature tourism, trekking which is part of tourismadventure. So it is implied in the law describes the existence of Jatiluwih Village as a Tourism Village.

Referring to the purpose of developing community-based tourism or known as Community Based Tourism, the community should be involved in tourism development. The people of Jatiluwih village in this case have less participation in the development and management of the village. ${ }^{2}$ Although there are already local regulations and the Bupati's decision on Jatiluwih Tourism Village, their tourism development is still less economical for the community, instead it tends to increase the sale of land and parking lot in the area.

The involvement of local communities and the availability of regulations to support the development of tourism in Jatiluwih Village is needed to actualize the community-based tourism. Thus it is necessary to review the management of Jatiluwih tourism village based on the participation of the community in detail.

Thus based on the above background, the problem formulation in this paper is (1) How is the availability of regulation about the management of Jatiluwih tourism village which refers to Community Based Tourism (CBT)?

(2) How is the involvement of Jatiluwih tourism village management capable to increase public participation in touris $\mathrm{m}$ development in Jatiluwih village?

\section{RESEARCH METHODS}

The research method used in this paper is empirical law research that is the research on the effectiveness of regulation implementation on Jatiluwih Village Management in Tabanan Regency to the management of community-based tourism (CBT). So in this paper the data obtained is a secondary data namely in the form of regulation both regency of Tabanan regency, Bupati Decree, and so on. Primary data were obtained by field or community research. ${ }^{3}$

\section{DISCUSSION}

\section{A. Availability of Regulations on Jatiluwih Tourism Village Management Referring to Community Based Tourism (CBT)}

Jatiluwih village is a tourist village located in District Penebel, Tabanan regency. This tourist village has a beautiful natural panorama with uniqueness terraces staircase located at the foot of Mount Batukaru. The air is relatively cool because it is located at an altitude of 700 meters above sea level.

\footnotetext{
${ }^{2}$ Dewa Ayu Diyah Sri Widari, “The Development of Jatiluwih Village after UNESCO Stipulated Subak as Part of World Cultural Heritage", Jumpa, Vo. 3, 2015, p. 63.

3 Soerjono Soekanto, Introduction to legal Research, Jakarta: UI Press, 2015, p. 52
}

Another peculiarity of Jatiluwih tourist village is the irrigation system known as Subak. Subak is a source of agricultural water that is organized directly from mountain water. Subak Jatiluwih village led by a Pekaseh and for subak led by Kelian Subak, currently ther are 7 Subak in Jatiluwih Village.

With the establishment of Subak in the village of Jatiluwih into World Cultural Heritage by UNESCO, the existence of subak is also another potential that is owned by Jatiluwih Tourism Village in addition to the beauty of rice terraces as Tourism Attractions. Subak management is therefore designated as a world cultural heritage needs to be further enhanced mainly through Community Based Tourism(CBT).

CBT is a development model that provides the greatest opportunity to local people to participate in tourism development. CBT is defined as an alternative form of tourism that uses local culture and the environment or rural nature as a form of involvement of community members in local business development. ${ }^{4}$ CBT is realized through the idea of activities and management that are all done by the community in a participatory manner and the benefits are felt directly by the local community.

In its development, tourism village is one of other form of application of CBT as a sustainable touris m development effort by involving local communities. The existence of tourist villages make tourism more imaging culture with typical rural so that the development of tourist villages still maintain the cultural values without having to destroy it. ${ }^{5}$

If you see the uniqueness of Jatiluwih Tourism Village which is patterned by agrarian religious according to the result of interview with Secretary of Village, at this time the agriculture activity in Jatiluwih no longer completely done traditionally; for example on certain days i.e. Purnama and Tilem plowing of rice field no longer use cow but using a tractor tool. This is due to the development of technology and indeed coincides with the prayers in the village.

The development of the community followed by technological developments implies the reduced participation of local communities in the management of Jatiluwih tourist village. In addition to technological factors, existing regulations are also less able to bind local communities to be involved in the management of tourist villages.

CBT will essentially involve the community in all stages of development; from planning, decision making, and monitoring of village tourism development programs. Community participation in the planning of a tourist village indirectly can encourage them to participate actively in the implementation and supervision.

In the planning stages stated in Tabanan District Regulation Number11 of 2012 on Spatial Planning of Tabanan Regency Year 2012-2032 (RTRWK Tabanan) pursuant to Article 107

\footnotetext{
${ }^{4}$ Ernawati, Dale Sanders, Ross Dowling, "Host-Guest Orientations of Community-based Tourism Products: A Case Study in Bali, Indonesia", Int J Tourism Res. 2017;19:367-382. https://doi.org/10/1002/jtr.2119.

5 Made Heny Urmila Dewi, "Development of Village Based on Tourism Local Community Participation in Jatiluwih Tourism Village Tabanan, Bali, Kawistara, 17 Agustus 2013, p. 131.
} 
paragraph (2), the role of the community in the preparation of spatial plan can provide input in the form of: (a) Preparation of spatial planning; Determining the direction of regional or regional development; Identification of potential and regional or territory issues; The formulation of the conception of plan or space; And the determination of spatial plans. As is known indeed in Perda RTRWK Tabanan Year 2012, Tourism Village Jatiluwih entered into one tourist attraction area (DTW) as listed in Article 51 paragraph (4) which has the potential DTW nature, adventure touris $m$, and cultural tourism.

From the results of the research shows that most of the local community Jatiluwih not involved in spatial planning related to the development of Jatiluwih Tourism Village. Whereas in this stage it is necessary community involvement to see more and more development of tourism facilities such as villas and restaurants. According to the Village Secretary's statement, in accordance with the results of discussion of desa pakraman agreed that the mechanism of development of tourism facilities, such as cafe built on initiative by local community and the land is pelabe (property) Pura Dalem. for example is Cafe Jatiluwih wihich used to be managed by local people. However, in the middle of the road management is less than the maximum, consequently café suffered losses. Until finally this café was contracted by Desa Adat, but in the process of making decisions about lease, contract period, and other matters related to public contract agreement; the community were not involved. This implies that the government as policy holders apply top down regulations that ultimately make the Jatiluwih community not accustomed to participate.

In addition to the planning phase, in the management of community-based tourism implementation or development stage, based on the results of research in the field, there is an increase in the number of tourism facilities in Jatiluwih village before Subak is designated as Cultural Heritage only 9 (Nine) restaurants while up to 2016 to 12 (twelve) and 6 (six) homestay. The existing restaurant consists of: Restaurant Padi Bali, Warung Krishna, Warung Wayan, Restaurant Gong Jatiluwih, Restaurant Terrace Subak, Warung Dea, Restaurant J-Terrace, Galang Kangin Restaurant, Warung Ada, Warung Deo, Billy's Restaurant, Waka Land Cruise . While homestay amounted to 6 (six) consists of: Teras Subak Homestay, Galang Kangin Homestay, Billy's Homestay, Dasavayu Homestay, Sang Giri Homestay, Dwantea Homestay.

The development of tourism facilities such as villas and restaurants in Jatiluwih village, especially after being designated as a Cultural Heritage by UNESCO gives the impact of the lack of community participation. Based on the results of interviews there are restaurant businesses that are not in accordance with the provisions of the local village, which is associated with Gong Jatiluwih restaurant which has a large parking area. According to the adat village, in awig-awig it is not allowed because it will further narrow the land or roads that exist around the area Jatiluwih.

Nevertheless, in the village tourism management stage it can not be separated from the involvement of the community; Especially local customary villages. Therefore, to affirm the direct participation of the community in the management of
Jatiluwih Tourism Village, a Regional Government Cooperation Agreement with Jatiluwih Village, Pakraman Jatiluwih Village and Gunung Sari Serta Subak Jatiluwih Year 2014 was established.

The form of Cooperation conducted between the Government of Tabanan District with Jatiluwih Village is related to the distribution of the results. In Article 2 paragraph (3), Distribution of the result of touris m attraction management needs to be adjusted to the contribution and needs that exist on the parties in supporting tourism activities in the Tourism Destination area. Furthermore, in Article 3 paragraph (1) The magnitude of the division of touris $m$ attraction is regulated as follows:

a. Operational Management Costs are submitted by the Operations Manager to the Chairman of the Management Body in accordance with the real needs in managing tourist attraction annually.

b. The operational cost of the letter a is as high as $25 \%$ calculated from the gross income minus the insurance premium.

c. DTW Development and Promotion Fee is set as high as $15 \%$ of the gross proceeds after deducting the insurance and operational management expenses of DTW with details:

1) $10 \%$ development cost;

2) $5 \%$ promotion fee

d. Etc..

So the overall tourism revenue in Jatiluwih Village obtained is given to $45 \%$ Kabupaten Government and Jatiluwih Village by $55 \%$. The distribution for Jatiluwih Village in Article 3 paragraph (2), after being made $100 \%$ is regulated as follows:

a. Jatiluwih Village $25 \%$

b. Desa Pakraman Jatiluwih $30 \%$

c. Desa Pakraman Gunung Sari $20 \%$

d. Subak Jatiluwih $21 \%$

e. Subak Abian Jatiluwih 2\%

f. Subak Abian Gunung Sari 2\%

The availability of regulation in the management of Jatiluwih tourist village shows that the income generated is intended for local communities with an even distribution of the results. Although community participation in management is still in the stage of admission revenue from tourism managed by the Government of Tabanan and Jatiluwih.

In addition to the planning and management phase involving community participation, the next stage is the supervisory phase. In the supervision stage is defined as the control carried out by the community in the management of Jatiluwih tourist village. Reaffirming through The Decree Bupati Tabanan Reg. 180/337/03 / HK \& HAM / 2016 about Jatiluwih Village as Tourism Village in Tabanan Regency. With the Decree, the public is involved in the controlling related to the participation of tourism activities. It is realized in the activities of hygiene, greening, and report all tourism activities in the village to the Department of Culture and Tourism Tabanan regency.

After the stipulation of Subak as World Cultural Heritage, based on Regent Regulation Number 84 Tabanan Year 2013 then formed Jatiluwih Tourism Management Board under the 
Regent of Tabanan directly. However, in the implementation in the village of Jatiluwih, Jatiluwih Tourism Management Board Attractions conducted directly by the local community. This means that the community is involved in the operational aspects of the local community there working on the Jatiluwih Tourism Management Board.

Public participation in conducting active supervision is done from pecalang (one of village official) which is also assigned as entrance guard, picket officer, parking officer, to guide trekking tour which involves the community directly. Daily checks are made on the payment of user fees as part of the operational management of the Tourism Resources Management Board. From there will be obtained the amount of income from tourist visits.

The increasing number of visits, giving implications for the increased development of tourism facilities. Even the development of tourism tend to be uncontrolled and not in accordance with the rules of spatial. In this case both Bendesa Adat and Pekaseh have not been able to take firm action to see that the absence of special regulatory area.

Poor community participation in the supervision stage of Jatiluwih tourist village management had an impact on the ineffectiveness of Jatiluwih village management. Starting from the top down stage of planning to create dissatisfaction in the community because it will only run programs that have been determined by the policy holder. So hopefully the Government of Tabanan more active to be able to explore the potential and involve the community in the development of Jatiluwih tourist village.

\section{B. The Management of Village Tourism Jatiluwih To Increase CBT In Development of Jatiluwih Village}

The development of tourism in Bali particularly has been proclaimed by the local government which is contained in Local Regulation No. 2 of 2012 on Bali Cultural Tourism Article 4 letter $b$ stated that the development of Bali Tourism is directed to improve the welfare of Balinese people equally and also for sustainable development. Through this Bali regulation then tourism management in Tabanan regency is set forth in Local Regulation of Tabanan Regency No. 4 of 2013 on Tourism which in Article 5 that tourism is organized with the principle of giving benefits to the welfare of the society, justice, equality, and proportionality and as much as possible to empower the local community. As such provision, the management of Jatiluwih village as one of tourism object must have notice to the empowerment local community optimally.

If we seeing at the rapid investment in the Jatiluwih village, the development of tourism facilities such as restaurant, villa, homestay that showed the increasingly marginalization of local community. How come, according results of interview with the village government, the land who is own by local community then sold it to investors was built not in accordance and also violate the spatial planning in Jatiluwih village. Ironically the business place such as restaurant or villa is sometimes hire people who is the former owner of the land before. Even though the new paradigm in the field of investment, especially in the regions is full autonomy to the regions to manage their resources. ${ }^{6}$

However, the positive impact is the increasing number of tourism facilities especially after Subak set as World Cultural Heritage, then a lot of business including restaurant, villa, etc. around area Jatiluwih needs more employees. The employees from local communities after establishment of Subak as World Cultural Heritage by UNESCO are increased amount 63 peoples from before only hired 48 employees.

The economic aspect, income which generated by Jatiluwih tourism village is not only derived from existing tourism business but also it gets from tourism management income in the form of entrance fee and parking ticket. Gross revenue obtained by Jatiluwih Tourism Management Board from income entrance ticket in 2016 amounting to IDR 4.683.655.500,00. Meanwhile parking fee IDR 251.107.500,00. The total number of revenues has increased annually since Subak was established as a World Cultural Heritage.

Based on Mutual Agreement between The Government of Tabanan District and Jatiluwih Village on the Result Sharing Article 3 states that $25 \%$ operational cost is managed by the Jatiluwih Tourism Management Board with calculated from gross income reduced by insurance premiums. Development and Promotion Cost is set at $15 \%$ of gross income after deducting insurance and operational management cost $(10 \%$ Development, 5\% Promotion, 10\% Management).

The income received from the management of Jatiluwih is obtained from balance income every year. Under the terms of the Mutual Agreement between The Government of Tabanan District is $45 \%$ and the Village is $55 \%$. Therefore, the income received by the village is redistributed to the Village Office 25\%, Desa Adat/Desa Pakraman Jatiluwih (Traditional Village) $30 \%$, Desa Adat Gunungsari 20\%, Subak Jatiluwih 21\%, Subak Abian Jatiluwih 2\%, Subak Abian Gunungsari $2 \%$.

The income results is used to finance religious ceremonies and for the continuity of local society in menyama braya (socialized among peoples in society). According with the division, Jatiluwih Village communities is no longer needs to pay when they have the compulsory dues at religious ceremony so that for local people the policy can alleviate the costs for religious ceremonies.

Participation of local communities in tourism village management is by managing resources in accordance as it has been determined by policy holders. As stated in the Regional Regulation of Tabanan District No. 4 of 2013 on Tourism,

\footnotetext{
6 Ana Rokhmatussa'dyah \& Suratman, The law of investment and Capital Market, Jakarta : Sinar Grafika, p. 89.
} 
Article 5 that the conduct of Tourism is based on the following principles :

a. Upholding the norms of religion and cultural values as the embodiment of the concept of life in the balance of the relationship between man and God Almighty, the relationship between man and his fellow human beings, and the relationship between humans and the environment in Hinduism known as Tri Hita Karana;

b. Upholding human rights, cultural diversity, and local wisdom;

c. Provide benefits to the welfare of the people, justice, equality and proportionality;

d. Maintain nature and the environment

e. Empowering local communities;

f. Ensuring integration between sectors, region, central and regional districts which is a systematic unity within the framework of regional autonomy, as well as the integration of stakehorlders;

g. etc.

based on that terms, the local communities of village Jatiluwih in the management of atourist village should have to do (1) develop a tourism village based on the Tri Hita Karana philosophy, harmonizing the relationship between God (Parahyangan), human intercourse (Pawongan), and also preserve the environment (Palemahan). (2) the local communities should have the right to participate in bulding tourism in Jatiluwih village by maintaining what is unique from Jatiluwih village. (3) the local communities becomes central to the management of tourist village. (4) maintain environmental sustainability by giving strict action against every violation the spatial planning at desa pakraman in order to development of tourism facilities. (5) the utilization of people's house as an alternative hostelry to empower the community. (6) collaboration with local government should be bottom up with directly participation of community in tourism development so as to prosper the society itself.

The development of tourism in Jatiluwih village requires involvement local communities in particular. Because in it there are uniqueness, local wisdom, and culture that can be turn on only by the local community. Therefore, management must involve community participation in order to keep the values of local wisdom and local customs. But in the process of management Jatiluwih village it is undeniable to require a solid partnership between local government, the investors, and of course the local community who is the stakeholders of the created cooperation. The three stakehorlders are in a mutually coordinated position and do mutually respectful cooperation without any intervention of their own interests.

\section{CONCLUSION}

Community Based Tourism (CBT) is defined as an alternative form of tourism that uses local culture and the environment or rural nature as a form on involvement of community members in local business development. CBT is realized in three stages of community participation, namely the planning, management or implementation stage, and the supervisory phase. Jatiluwih tourism village is one of the areas that development CBT system. At the planning stage of community participation in the management of Jatiluwih tourism village is still less than the maximum despite the existing regulations that regulate. In the Regional Regulation of Spatial Planning of Tabanan Dis trict No. 11 of 2012, Article 107 Paragraph (2), the form of the role of the community in the preparation of spatial plans can provide input in the form of : a. Preparation of spatial planning; Determining the direction of regional or regional development; identification of potential and regional or territory issues; the formulation of the conception of plan or space; and the determination of spatial plans. That is means in the planning stages of restaurant which is built on the land of Pelabe Pura Dalem (own by village) in the process of making decisions about lease, contract period, and other matters related to public contract agreement is not involved by the local government. Second, stage of management or implementation that show the involvement of the community, especially the traditional village is the existence of a form of mutual agreement between the Government of Tabanan District with Jatiluwih village. The mutual agreement between Local Government with Jatiluwih Village 2014 on Sharing Income declared that the local government get $45 \%$ and Jatiluwih village get $55 \%$. Meanwhile, in the stage of supervision based on Regent Regulation Tabanan District No. 84 year 2013 then formed Jatiluwih Tourism Management Board. The participation of community supervising here by involvement Pecalang (security) as entrance gatekeeper, parking officer which every day have to re-check payment retribution of visitor as a part of management of Jatiluwih Tourism Management Board.

Increasing amount tourism facilities especially after Subak established as World Cultural Heritage, it affect the business around area Jatiluwih tourism village needs more employees. Despite that facts, the rapid investment in Jatiluwih village showed the marginalized of local community to have an opportunity to expand their business. According to the distribution of results based on Mutual Agreement between Local Government and Jatiluwih Village, at least Jatiluwih village community is no longer needs to pay obligatory dues of religious ceremony. So that for local peoples the policy can relieve cost incurred for religious ceremony. Furthermore, the development of tourism in Jatiluwih village not only requires a solid partnership between Local Government, Investors, and local communities, but also needs using CBT system to create tourism development that retains culture, local wisdom, and customs of Jatiluwih village. 


\section{REFERENCES}

[1] Dewa Ayu Diyah Sri Widari, "The Development of Jatiluwih Village after UNESCO Stipulated Subak as Part of World Cultural Heritage", Jumpa, Vo. 3, 2015.

[2] Soerjono Soekanto, Introduction to legal Research, Jakarta: UI Press, 2015.

[3] Ernawati, Dale Sanders, Ross Dowling, "Host-Guest Orientations of Community-based Tourism Products: A Case Study in Bali, Indonesia", Int $J$ Tourism Res.2017;19:367-382. https://doi.org/10/1002/jtr.2119.

[4] Made Heny Urmila Dewi, "Development of Village Based on Tourism Local Community Participation in Jatiluwih Tourism Village Tabanan, Bali, Kawistara, 17 Agustus 2013.

[5] Ana Rokhmatussa'dyah \& Suratman, The law of investment and Capital Market, Jakarta : Sinar Grafika.

[6] Local Regulation No. 2 of 2012 on Bali Cultural Tourism.

[7] Tabanan District Regulation number 11 of 2012 on Spatial Planning of Tabanan Regency Year 2012 - 2032.

[8] Local Regulation of Tabanan Regency No. 4 of 2013 on Tourism.

[9] Decree of Bupati Tabanan Reg. 180/337/03 / HK \& HAM / 2016 about Jatiluwih Village as Tourism Village in Tabanan Regency

[10] Decree of the Regent of Tabanan 180/337/03 / HK \& HAM / 2016 on Stipulation of Jatiluwih Village as Tourism Village in Tabanan Regency.

[11] Mutual Agreement between The Government of Tabanan District and Jatiluwih Village on the Result Sharing Year 2014. 